\title{
Banal interculturalism: Latin Americans in Elephant and Castle, London
}

\section{Adriana Patiño-Santos}

\author{
University of Southampton
}

Rosina Márquez Reiter

University of Surrey

\begin{abstract}
This paper discusses banal interculturalism as produced in an interview situation with migrants of Latin American background in London. Banal interculturalism emerges within discursive semiotic processes that allow the participants to display their (cultural) knowledge about co-ethnics and their practices, to position themselves in opposition to the 'others' within diaspora, and to justify their, typically negative, views towards other migrants. Sources of that knowledge can be experiential, though in most cases consist of hearsay evidence. This notion may assist intercultural communication scholars in understanding how intra-group relations are conceived and the consequences for migrants of the discourses they themselves spread within the wider group.
\end{abstract}

\section{Resumen}

Este artículo discute la noción interculturalidad banal, producida en una situación de entrevista con migrantes de origen latinoamericano en Londres. La interculturalidad banal emerge a través de procesos semiótico-discursivos que permiten a los participantes desplegar su conocimiento (cultural) sobre otros migrantes de la misma región geográfica y sus prácticas, posicionarse en oposición a los 'otros' dentro de la diáspora y justificar sus visiones, normalmente negativas, sobre otros inmigrantes. Las fuentes de esos conocimientos son experienciales o evidencia de segunda mano. Consideramos que esta noción podría ser útil para los investigadores interesados en la comunicación intercultural pues permitiría dar cuenta de cómo se construyen las relaciones internas de los grupos y de las consecuencias de los discursos que circulan entre la misma comunidad para los propios migrantes. 
Key words: banal interculturalism, Latin Americans in London, discriminatory discourse, othering, positioning.

\section{Introduction}

The discriminatory discursive practices of larger dominant social groups towards newcomers and minorities have received important attention from various disciplines concerned with the role of language in the production and reproduction of social differentiation and stratification, especially though not limited to Critical Discourse Analysis, Linguistic Anthropology, Transnational Studies and Social Psychology. Findings have increased awareness of how racism and other forms of discrimination are materialised and transmitted through discourse. Although research has primarily focused on the discriminatory discursive practices that emerge from the contact between dominant and minority groups (e.g. Hill, 1998 on Mock Spanish as a register of 'Anglo-Spanish'; Urciuoli, 1996 on prejudice towards Puerto Ricans in New York; Zentella, 2003 on Anglo racist discourse towards Latinos), some have also considered such practices between different minority groups (e.g. Bailey, 2000 on conflict between Korean immigrant retailers and African-American clients). However, little attention has been paid to the existence of similar practices among members of the same ethnolinguistic group, especially when the group has not achieved full societal inclusion (see, for example, Aranda et al. 2014 on inter-Latino hierarchies in Miami). This study contributes to the body of knowledge that has examined discriminatory discursive practices by offering an analysis of the ways in which a group of culturally diverse Spanish-speaking Latin Americans (SsLAs), in Elephant \& Castle, Southwark, Greater London, categorise each other. The paper shows that most of these categorisations are constructed through semiotic 
discursive processes that, under the guise of truth, perpetuate the spreading of prejudices. These categorisations are based on the experiential knowledge members of the group have of each other based on their quotidian encounters in diaspora but also on hearsay. In this sense, therefore, we refer to this process as banal interculturalism, inspired by Billig's banal nationalism (1995). Banal interculturalism refers to the forms of intercultural knowledge displayed by the participants in their discursive practices and used to legitimate their evaluations of, and behaviours towards 'the others'. ${ }^{1}$ The discourses that interest us concern the characteristics that SsLAs ascribe to each other. Such characteristics provide 'evidence' of the differences they perceive between themselves and the prejudices that exist among members of the group. After presenting an overview of SsLAs in London, we discuss the theoretical understanding that informs banal interculturalism. This is then followed by our methodological approach and the analysis and discussion.

\section{Research Context}

The presence of SsLAs in the UK remained until recently underexplored relative to more established migrant groups. Most of the studies conducted have thus focused on making Latin Americans visible in the UK by providing information on their socio demographic profile, especially in London where almost half of the population lives (c. 250,000 in the UK and 145,000 in London, McIllwaine \& Bunge, 2016). Block (2007) offered one of the earliest exploratory studies of Latin Americans in London based on interviews with the then cleaning staff at the University of London. He reports the emergence of a new Latin American identity based on complex issues, including deskilling, the lack of a community feeling and low English proficiency. Indeed, access to English was then and still is today identified as one of the major barriers to mobility by Latin Americans given their dominant work-oriented migratory trajectories and the lack of access to accessible ESOL tuition. Granada's (2013) 
work within a Refugee Migrant Organisation and the Latin American Recognition Campaign delved into the linguistic and social inequalities that Latin Americans face including issues of identity toward their L1 and English. The results of her study highlight the importance of ethnic recognition as an avenue towards social inclusion. Kelsall (2015) linguistic ethnographic study in a Latin American complementary school in London, also highlights the need for the community to maximise the appeal of its heritage to gain recognition and resources. Despite the attested presence of Spanish and SsLAs in the front shops of small businesses and eateries located in Latin American clusters in and around Elephant \& Castle (E\&C) (Southwark) and Seven Sisters (Haringey) and the traditionally Spanish enclave of Portobello in Notting Hill (Paffey, in press), they face marginalisation with respect to more established groups (Márquez Reiter \& Martín Rojo, 2015). SsLAs work primarily in the service sector (e.g. cleaning and catering) for co-ethnics where knowledge of English is not, strictly speaking, necessary. Our own linguistic ethnographic research echoes the issues raised by prior studies and turns its attention to the way in which established Latin American retailers in Elephant \& Castle who migrated in the 90s construct themselves as moral agents against the background of intense urban transformation in this area (Márquez Reiter \& Patiño-Santos, 2017). It brings into focus the intra-group tensions that emerge from the imminent displacement of retailers housed inside the Elephant \& Castle shopping centre vis à vis those whose businesses are situated in and around the mall, as well as their aspirations for a yet uncertain future.

Broadly speaking, Latin American is the official label used to refer to people who originated from Latin America. Brazilians constitute the largest national group followed by Colombians, Ecuadorians, Bolivians and Peruvians, Bolivians (McIlwaine, et al 2011). ${ }^{2}$ Our fieldwork took place in and around Elephant \& Castle. SsLAs are defined as an ethnic group that share historical and cultural traits beyond their use of the Spanish language, such as eating habits 
and religious affiliations. The current migration patterns of SsLAs - either arriving as students or tourists often overstaying their visa and becoming '(ir)regular' migrants or, more recently, the arrival of onward migrants, principally from Spain with European passports make it difficult to estimate their precise numbers (McIlwaine \& Bunge, 2016).

The arrival of SsLAs was marked by political and economic unrest in their countries of origin. Thus, the 70s witnessed the arrival of political exiles fleeing from dictatorships in countries such as Argentina, Chile and Uruguay. They were mostly middle-class and well-educated. In the late 1980s and early 1990s the city saw the arrival of significant voluntary migration from Latin America, as well as Colombians and Ecuadorians seeking asylum. They began to settle in poor areas of the city, such as Southwark. Although most of them fed into the low skilled cheap labour market, a few of them soon saw entrepreneurship as a way to 'shortcut' the occupational ladder (Márquez-Reiter \& Patiño-Santos, 2017). This era also initiated a generational division in terms of access to material resources and (linguistic) inclusion. Unlike SsLAs who arrived in the 80s and 90s, those who came after then could not access funded ESOL tuition or other forms of local government support.

The composition of the SsLAs social group has varied since the beginning, especially since the mid-2000s due to changes in UK visa requirements, prioritising highly skilled migrants, along with the arrival of onward migration from other European countries, primarily from Spain, in the aftermath of the economic crisis of 2008. Onward migrants are legally entitled to live and work in the UK, but now face similar challenges as any other EEA national, for instance in terms of language learning given that budget for ESOL funding has been significantly reduced (Casey Review, 2016).

\section{Elephant \&Castle - a place of social stratification}


The E\&C area has hosted SsLAs, particularly in the premises within the shopping centre, since the beginning of the 1990s (Roman-Velázquez, 1999; Roman-Veláquez \& Hill, 2016). At the time of our research, there were 96 Latin American shops in the area (travel agencies, restaurants, hair and beauty salons, clothes shops, money transfer shops, etc.). 12 of these were located in the shopping centre. Our own research in the area evidenced an internal division between SsLAs who have been in the area since the 1990s and those who began to arrive from 2008 onwards, particularly onward migrants from Spain. The former group, especially those retailers who arrived first control many of the resources, such as leases, and access to employment in the area. Having arrived first, they created the material conditions for subsequent flows of SsLAs. For that reason they portray themselves as the pioneers and 'builders' of what E\&C represents today for SsLAs in the city: a commercial centre but, perhaps more importantly, a ready-made locus of social relations for newcomers who do not speak English and who are looking for employment and social access, including professional advice on documentation, legal information and the like. First arrivals present themselves as hard workers who, having struggled with lingua-cultural barriers, eventually acquired the knowledge and necessary skills to participate in the host city. Consequently, they have the means to include or exclude new arrivals by controlling access to rents and employment contracts. $^{3}$

On various occasions, we have observed the tensions that existed between co-ethnics with different migration trajectories as well as between those who come from different regions of the same country. This is especially relevant at a time when their place in London and their livelihoods are being threatened as a result of economic pressures. It is precisely against this background that the cases of banal interculturalism we discuss in this paper are set.

\section{Theoretical considerations}


The paper examines discursive categorisations of SsLAs constructed in the situated communicative arena of life story interviews (Atkinson, 1998) in which SsLAs participated as interviewers and interviewees. Interviews are interactionally achieved social occasions where participants position themselves with respect to the interactional roles they assume throughout the encounter and the stances they take relative to one another (Márquez Reiter, 2018). As the analysis shows, banal interculturalism emerges and is further articulated in light of the interviewers' contributions and their reactions to those made by the interviewees in their capacity as Colombian and Uruguayan migrants in London. The interviewers are positioned by the interviewees as knowledgeable subjects of their respective cultures and of the alleged fixity and transplantation of their cultural traits.

Studies on 'othering' from discursive perspectives have attested (Urciuoli, 1996) that categorisations about the 'others' are constructed through semiotic resources, which, under the guise of 'truth', perpetuate the spreading of fixed ideas about theses "others" (stereotypes and prejudices). These categorisations are based on the experiential knowledge members of the group report having of each other, mainly based on their day-to-day encounters in diaspora. The ways in which they are (re)produced in interaction index complex social relations among these migrants (e.g. Roth, 2016) where 'knowledge' about others is perceived as 'normal' or 'natural' by the producers. For that reason, perceived differences in social class, length of residence, migratory trajectories, levels of education, etc., are made relevant by the social actors in the dynamics of the interviews in which they were constructed. In the context of this study, banal interculturalism refers to the normality within which categorisations of the other are produced and circulate. Banal interculturalism is thus a form of knowledge about the 'others' based on lived experience. Those who construct themselves as 'knowledgeable' subjects spread ideas and beliefs about the 'others', based on their everyday encounters with other SsLAs who do not share the same linguistic or migratory 
trajectories or cultural experiences. Such knowledge is often articulated in terms of national ascriptions or differences, and shared or differing cultural practices (customs, traditions, ways of speaking and ways of acting) within the same ethnolinguistic group. This notion is inspired by Billig's banal nationalism (1995). Banal nationalism refers to the practices that spread national ideologies in the mundane activities of daily life such as through national celebrations where national flags and other national symbols are consciously waved, forecasting the weather on TV by pointing to the map of Great Britain as centrally located, and the like. The 'normality' with which 'othering' surfaces in multicultural environments, has received scholarly attention (e.g. Harris, 2013; Piller, 2012; Sandercock, 2003). In this study we adopt the adjective banal to refer to discursive processes that allow the migrants of our study to display their lived (cultural) knowledge about co-ethnics. Their source of knowledge is experiential though in most cases represents hearsay evidence (e.g. 'a friend of mine had this sort of experience with Ecuadorians'). In our data banal interculturalism is constructed by attributing positive or negative characteristics to people according to their place of origin, or according to sub-groupings based on criteria such as their arrival in London and their length of settlement. Banal interculturalism is used by the participants of our study to justify their views and behaviour towards other SsLAs migrants and to position themselves in opposition to 'others'. The banality we discuss stems from the types of categories and attributions that are used as criteria for differentiating between Latin Americans (Colombians v. Uruguayans, swindler v. honest). This leads to the homogenisation of sub-groups within the Latin American collective, primarily in terms of their national origin regardless of their social position. This is somewhat surprising given the relatively short length of settlement of Latin Americans in London (cf. Negrón, 2011 for processes of ethnic identification among Latinx in NY). The accounts we analyse here are 
likely to vary according to the social divisions that become relevant to these participants in constructing their positionings relative to others around them.

\section{Methods and data}

This study is an ethnographic account of our fieldwork conducted in Elephant \& Castle between the summers of 2014 and 2015. Our main aim was to explore and document how SsLAs in Elephant \& Castle experience the regeneration of the area and the ways in which they deal with such a critical moment in the life of their ethnolinguistic community. We visited and observed the shopping centre and surrounding area on frequent occasions, including weekends. A total of 60 days of visits were conducted. We identified and recorded in situ interviews with visitors and retailers during the first three months of our fieldwork. They consented to participate and allowed us to spend time with them during the day. Overall, we conducted life story interviews with ten retailers, and 12 other Latin Americans in restaurants, an estate agent's, a legal consultancy firm and two food stores for a bespoke radio programme on a local Latin American radio station aimed to capture the everyday lives of SsLAs in E\&C against the backdrop of regeneration. Each interview lasted between one hour and hour and a half. They generated a rich set of data comprising anecdotes, memories and evaluative statements such as opinions and assessments. Even though our initial focus was on how the regeneration plan affects Latin American migrants' lives in Elephant \& Castle, the themes addressed during the interviews were: their migratory trajectories, the reasons to migrate, anecdotes about their first years in London, their memories of Elephant \& Castle when they arrived, their views on the transformation of the place and the regeneration process. Interestingly, their perceptions of 'other' Latin Americans emerged as an unexpected theme which attracted our attention. From the 12 interviews collected, two with female migrants, Luci and Claudia, of Uruguayan and Colombian backgrounds represent the most 
widely spread discourses about 'other' Latin Americans that we collected in our data. We have thus selected them for analysis. Our experience as Latin American customers and as Latin Americans in London has also informed our interpretation of the data and guided our fieldwork.

An interactional discourse analysis of the life stories that emerged highlights how identity is constructed by categorising the 'self' and the 'others', especially as the participants assign attributes and react to attributions by accepting, rejecting or contesting them (Pavlenko \& Blackledge, 2004) in light of each other's contributions. The analysis pays attention to the discursive resources used by the participants to mark either implicitly or explicitly and reproduce ideas about 'other' Latin Americans during the course of the interview situation. Language indexes the many possible notions that exist about migrants' social relations, social definitions, types of people, and "natural" attributions assigned to groups of people that have practical repercussions.

The accounts we examine here are indicative of a dialogical relation between 'differentially situated' (Yuval-Davis, 2012) participants: the interviewers, the interviewee and those whose stories emerged in the interviews. Banal interculturalism is predominantly done through erasure (Irvine \& Gal, 2000), by which the complexity of human actors, social positions, and characteristics are 'reduced to a few key elements generally assumed to be natural, universal among all "those" kinds of people. The individual becomes the group writ small and vice versa' (Urciuoli, 2011, p. E119).Generalisations, essentialisations, exaggerated group attributes and superficial examples of what characterises a group are ways of erasing particularities. In Urciuoli's (2011) words they become 'social facts': “Real means real in people's social experience, felt physically and psychologically, with consequences" (2011, p. E113). The subjects who display knowledge, evaluate the people and situations that they are presenting by drawing mainly on us/them comparisons, extreme formulations (Pomerantz, 
1986), 'cultural' definitions, metacultural assessments (Urciuoli, 2011) and small stories (Georgakopoulou, 2007).

\section{Analysis}

The analysis of how banal interculturalism is constructed in discourse presents the ideas that circulate among SsLAs about 'other' SsLAs and the discursive resources used to describe them. By drawing on interviews with two female workers in Elephant \& Castle (Luci and Claudia), we will discuss how the participants construct themselves as knowledgeable selves, and the sources that they provide to give evidence of their intercultural knowledge (i.e. what they state about the 'others' and the forms used to define them through their habits, behaviour, and beliefs).

\subsection{Luci}

Our first interview was conducted at a Latin American salon with a Uruguayan hairdresser, Luci, in her mid-thirties. Luci came to London after migrating from her native city of Paysandú, (Uruguay) close to the border with Buenos Aires (Argentina). Luci explains that she decided to live and work in the area because of its pan-Latin American feel. The salon is owned by a Latin American originally from Colombia and has been serving the needs of the local community (Latin Americans, other migrants and 'locals' in the area) since the early 90s. It offers a full range of products and styles popular with Latin Americans (e.g. hair straightening, permanent blow-dry, hair extensions, etc.).

Based on her experience working in the salon for ten years, Luci has witnessed some of the changes in the area and has had the opportunity to interact with Latin Americans from different regions.

Excerpt 1 - 'It's very Colombian'

\begin{tabular}{|l|l|l|l|}
\hline 1 & Luci: & Hheh y (h) d (h) ej (h) aban (h) a todo[s m(h)ontado' en el \\
2 & & avión] & \\
$(\ldots)$ & $(\ldots)$ & $(\ldots)$ & \\
\hline
\end{tabular}




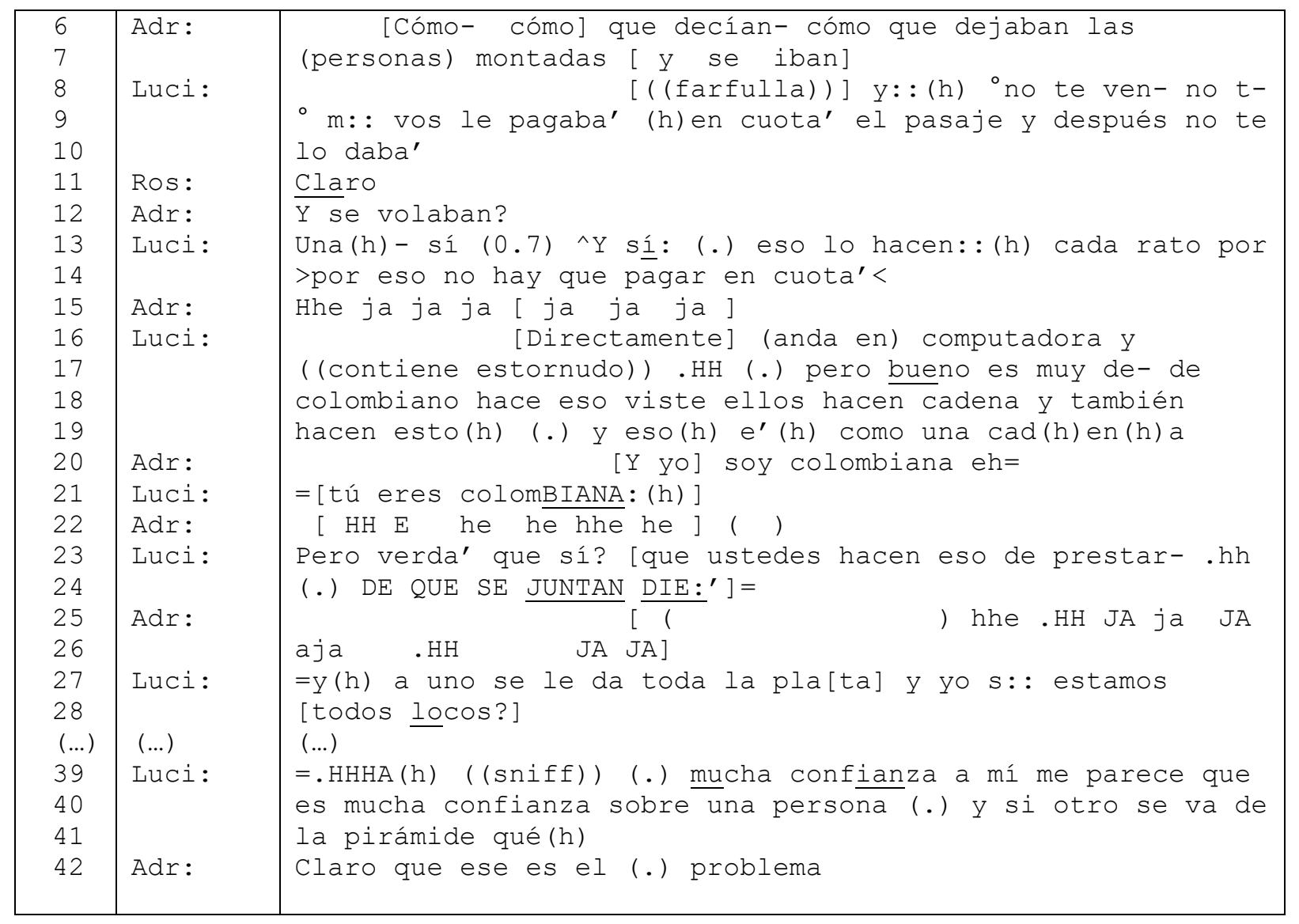

During the interview Luci focuses on Colombians. This possibly responds to the fact that her boss, friends and colleagues in the workplace are Colombian too. ${ }^{4}$ She thus has experiential knowledge of interacting with Colombians as part of her life in London. Also of note is the fact that one of the interviewers, Adriana, is Colombian. Although this was not relevant in the initial stages of the interview, upon Adriana's question Luci explains how the shopping centre had changed since her arrival. She talked about the various businesses that have existed in the shopping centre. One of these was a Colombian run travel agency that frequently changes hands. Luci explained earlier in the interview that they hacían sus cosas $y$ se iban - 'would do their things and leave'. Luci's depiction of Colombians as a collective that habitually engages in deceptive business practices via a colloquial Colombian expression in the imperfect - $d(h)$ ej(h)aban (h)a todo[s m(h)ontado' en el avión] - 'they [Colombians] left(h) everyone (h) sat on the plane]', in 1.1, thus reducing them to regular swindlers (11.17-9), 
thus logically follows from her preceding comment. Adriana immediately reacted by provided categorical self-identification finished with a tag (eh 1.20).

With this Adriana oriented to such banal interculturalism, i.e. the essentialisation of Colombians as fraudsters based on Luci's articulation of hearsay knowledge, as an interpersonally delicate activity (Hansen \& Márquez Reiter, 2016). Luci’s reaction, however, displays some surprise. This is observed by her latched follow up question oriented to seeking confirmation of Adriana's origin (1.21). With the alignment-seeking question and the increment that follows (1.23), Luci addresses Adriana as part of the Colombian collective via the second person plural (ustedes) while distancing herself from such immoral practices. This generates non-affiliative laughter by Adriana (11. 25-6). Lucy suggests, on the basis of her experiential knowledge with Colombians (1l.1-14 and 24; 39-41), that the illegal business practice of pirámide (in which payments are promised on condition that ever increasing numbers of people are brought into the scheme), mentioned during the interview as 'a Colombian thing', would require a level of trust. Such a level of trust stands in stark contrast to the distrustful nature that she has observed among Colombians.

Luci becomes the subject who knows and is thus in a position to assesses the behaviour that others engage in. Banal interculturalism, that is her knowledge about the others, is constructed through various discursive resources, such as essentialisations (fraudulent schemes as relevant to all Colombians in the diaspora, Colombians as one homogeneous group), negative categorisations (vos le pagaba' (h)en cuota' el pasaje y después no te lo daba - 'you would pay the ticket in instalments and then they wouldn't give it to you'), attribute intensifications via exaggerations (estamos [todos locos?] - 'are we [all crazy?]') (Drew, 2003) and a discourse of distancing (us v. them), facilitated by the fact that one of the interviewers is Uruguayan. She constructs swindling as a mundane practice on the basis of 
her own cultural logic in 11. 41-3 where she observes how the necessary conditions for trust are not met. Other resources to construct banal interculturalism are illustrated in Excerpt 2:

\section{Excerpt 2 - Essentialisation}

\begin{tabular}{|c|c|c|}
\hline $\begin{array}{l}1 \\
2 \\
3\end{array}$ & Ros: & $\begin{array}{l}\text { HH y qué otro cuentito de colombiano m[e tenés aparte de eso } \\
\text { de que se queda con el dinero que se queda con la plata y qué } \\
\text { otra cosa] }\end{array}$ \\
\hline 4 & Luci: & {$[\mathrm{T} . \mathrm{HHh}(\quad))$} \\
\hline 5 & & a $\mathrm{v} e \mathrm{r}) \quad \mathrm{m}: \mathrm{:} \quad \mathrm{H} \mathrm{H} \mathrm{h} \in(\mathrm{h})$ \\
\hline 6 & & . $h \mathrm{~h} \quad \mathrm{H} h \mathrm{~h}(\mathrm{~h})]$ que son los tal estafadore' \\
\hline 7 & & $\operatorname{VECE}^{\prime}(\mathrm{h}) \quad($.$) sí no (h) hhe (son m[edio)]$ \\
\hline 8 & Ros: & - $\quad[$ Colom]biano estafador dice= \\
\hline 9 & Luci: & $=$ son medio (h) estafador $\left[e^{\prime}(h)\right]$ \\
\hline 10 & Ros: & $-[. \mathrm{HH}]$ Y [qué otra cosa] \\
\hline 11 & Luci: & [hhehhe $\quad . \mathrm{HH}]$ \\
\hline 12 & Ros: & {$[$ FUMAN DEBAJO 'EL } \\
\hline 13 & Luci: & [Y COMO NOSOTRO' ${ }^{-}$NO] HA:Y sí O no? \\
\hline 14 & Ros: & $\operatorname{Ex}(\mathrm{h}) \operatorname{actam} \overline{(\mathrm{h}) \text { ente }} \quad \overline{ }$ \\
\hline 15 & Luci: & (0.3) y qué vamo' a h(h)hacer (.) [ es cierto el uru]guayo= \\
\hline 16 & Ros: & [y qué otro cuentito] \\
\hline 17 & Luci: & $=$ tenemo' cosas muy buenas \\
\hline 18 & Ros: & Como [qué por ejemplo] \\
\hline $\begin{array}{l}19 \\
20\end{array}$ & Luci: & 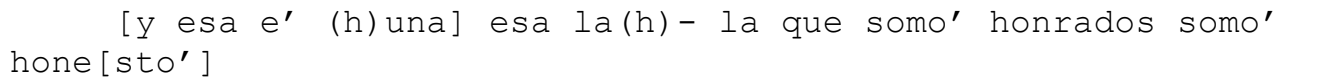 \\
\hline 21 & Ros: & [ Hon $] r[a d o s]$ \\
\hline 22 & Luci: & {$[. H H]$ No no andá no sé cómo se le' $(h)$ ocurre $(h)$ que te } \\
\hline 23 & & pueden cobrar un pasaje y después se largan con toda la plata y \\
\hline 24 & & no le'importa. HHh y es una estafa que ni siquiera tiene . ni \\
\hline 25 & & siquiera van presos (0.4) por esa estafa social eh?.hh $\bar{y}$ : le \\
\hline 26 & & estafan el-el-el- la plata $y-y-l a$ ilusión de ver a su familia \\
\hline
\end{tabular}

Luci continues to describe Colombians with exaggerated generalisations, albeit she does so hesitantly (11.4-6) and modulates them via adverbs and adjectives (11.4-5). She thus orients to the interpersonally sensitive nature with which her previous evaluations were received, at least by one of the interviewers, by attending to face (Goffman 1967) considerations. In an attempt to reach topic closure (1.12) as far as the 'swindling Colombians' are concerned and minimize the sensitivity that had arisen, the interviewer of Uruguayan origin, Rosina, draws on a humorous River Plate colloquial expression -FUMAN DEBAJO DEL AGUA 'THEY SMOKE UNDER WATER' - to move the interaction forward. The expression alludes to the ingeniousness, cleverness or resourcefulness of people. This is heard as 
affiliative as evidenced by Luci's reaction: a positive assessment constructed with an extreme formulation and finalised with a tag to mobilise agreement - [Y COMO NOSOTRO' NO] $\underline{H A: Y}$ sí o no? - '[AND THE:RE'S NOBODY LIKE US] IS THERE?'. This leads Luci to start contrasting the moral values of Uruguayans and Colombians (us v. them) in spite of Rosina's challenge of the alleged good qualities attributed to Uruguayans (1. 17) and her softer partial repeat - 1.19 hon]ra[dos ] - 'truth]f[ul]' - with which she registers the essentialisation and indicates some trouble with interviewee's action (e.g. Bolden, 2009). Luci constructs Colombians as morally different from Uruguayans based on her actual experience with Colombians in London and her cultural logic. She contrasts 'us' Uruguayans to 'them' Colombians by assigning positive explicit and implicit attributions to Uruguayans and by default the reverse to Colombians. Uruguayans, unlike Colombians, are 'truthful' and 'honest'. This is illustrated by the implicit positive attributions offered in 11.22-26 where she evaluates the actions attributed to Colombians vested by her lived knowledge and experience in diaspora. The use of 'they', to generalise the behaviour of 'Colombians', erases particularities of individuals within this social group, thus homogenising them. In 11.22-3, she uses a rhetorical question to evaluate Colombians' behaviour negatively. Her definition of the situation as estafa - 'fraud' in 11. 24-26 and her subsequent hypothetical closing of the story, allows her to present a final moral evaluation of the behaviour of Colombians that conveys a portrayal of ruthlessness and cruelty - y le estafan el- el- el-la plata y-y-la ilusión de ver a su familia - 'and they swindle the-the-the money and-and the hope of seeing their family'. Luci continues to display her knowledge of Colombians by introducing her personal experience as evidence. In Excerpt 3, she aims to present Colombians as untrusting by introducing her boss in a particular way. She constructs the characterisation of Colombians as mistrustful on the basis of her actual experience working and living with Colombians in London. 


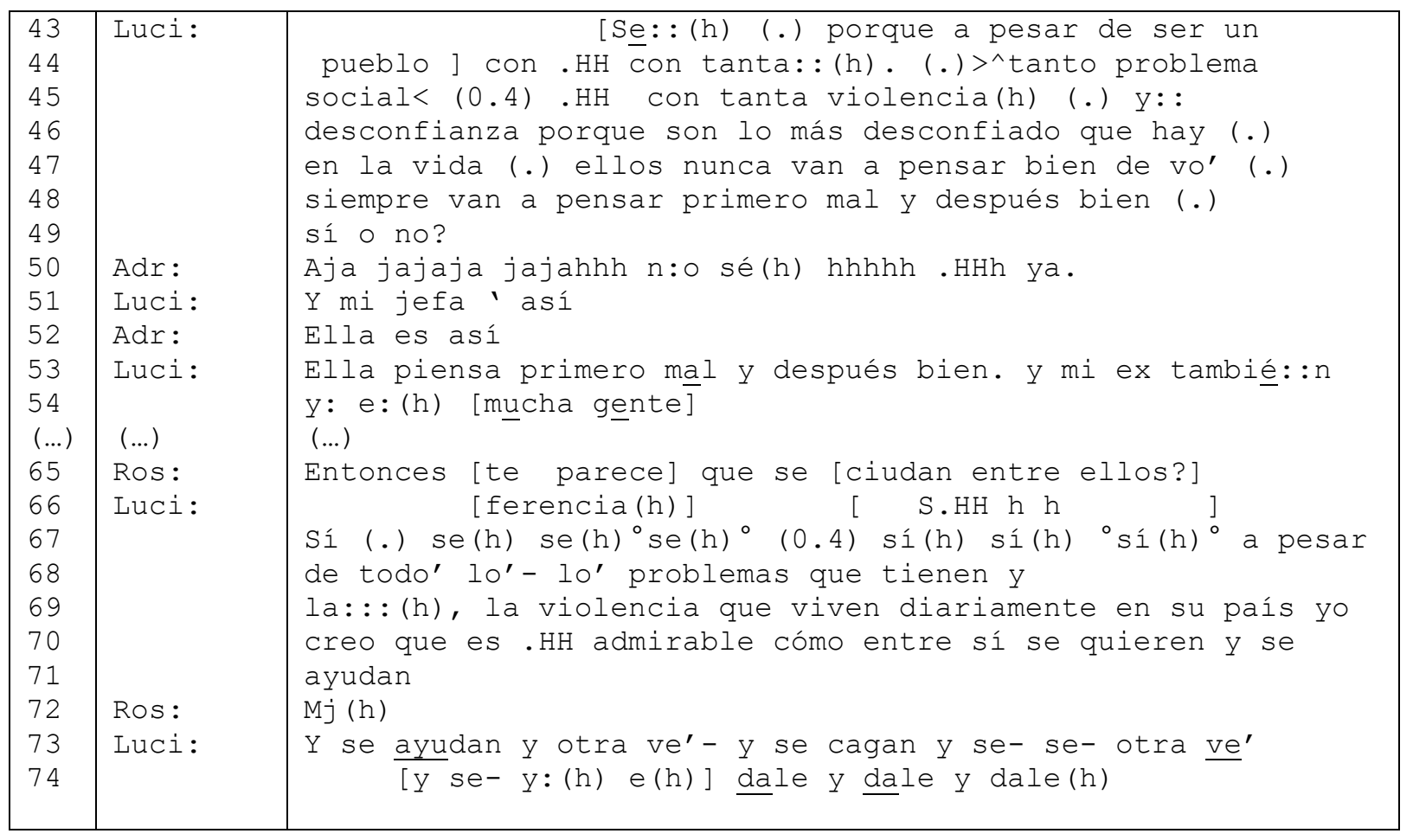

Despite her acknowledgement of the political struggles of the Colombian people, erasure through generalised definitions continues to be the discursive form through which Luci constructs her knowledge about them. Thus, after offering an explanation in which she mitigates her ideas about Colombians, Luci describes them with the generalisation son lo más desconfiado que hay - 'they're the most distrustful [people]' addressing Adriana, the interviewer of Colombian background, in 11.46-7. Luci defines the attribution 'distrustful' by adding the assertion siempre van a pensar primero mal - 'they will never think well of you'. Instead of affiliating with Luci's statement, Adriana, in 1.50, avoids answering and laughs. Luci then, illustrates her point by citing her boss, and later her ex-boyfriend. With this she justifies her evaluations as 'real facts' by recurring to primary knowledge rather than secondary or hearsay information. This first-hand knowledge, however, continues to be experiential and cannot be factually corroborated. 


\subsection{Claudia}

Claudia (19), a young migrant of Colombian origin, describes the group of Latin Americans who have migrated to the UK via Spain. She migrated originally from Colombia to Madrid with her mother, and has experienced a second relocation from Madrid to London. At the time of the interview, she had been living in London and working in the surroundings of the shopping centre in $\mathrm{E} \& \mathrm{C}$ for nearly two and a half years. The interview was conducted at her workplace, a legal consultancy firm where she works as a legal adviser. Within our data, Claudia represents the circulating discourses of those Latin American migrants who work on semi-skilled employment in diaspora. Her discourse is predominantly marked by forms of distancing from those migrants who work in menial jobs, such as cleaning. She is clearly portraying these migrants from a classist point of view.

Excerpt 4 - Sources of knowledge

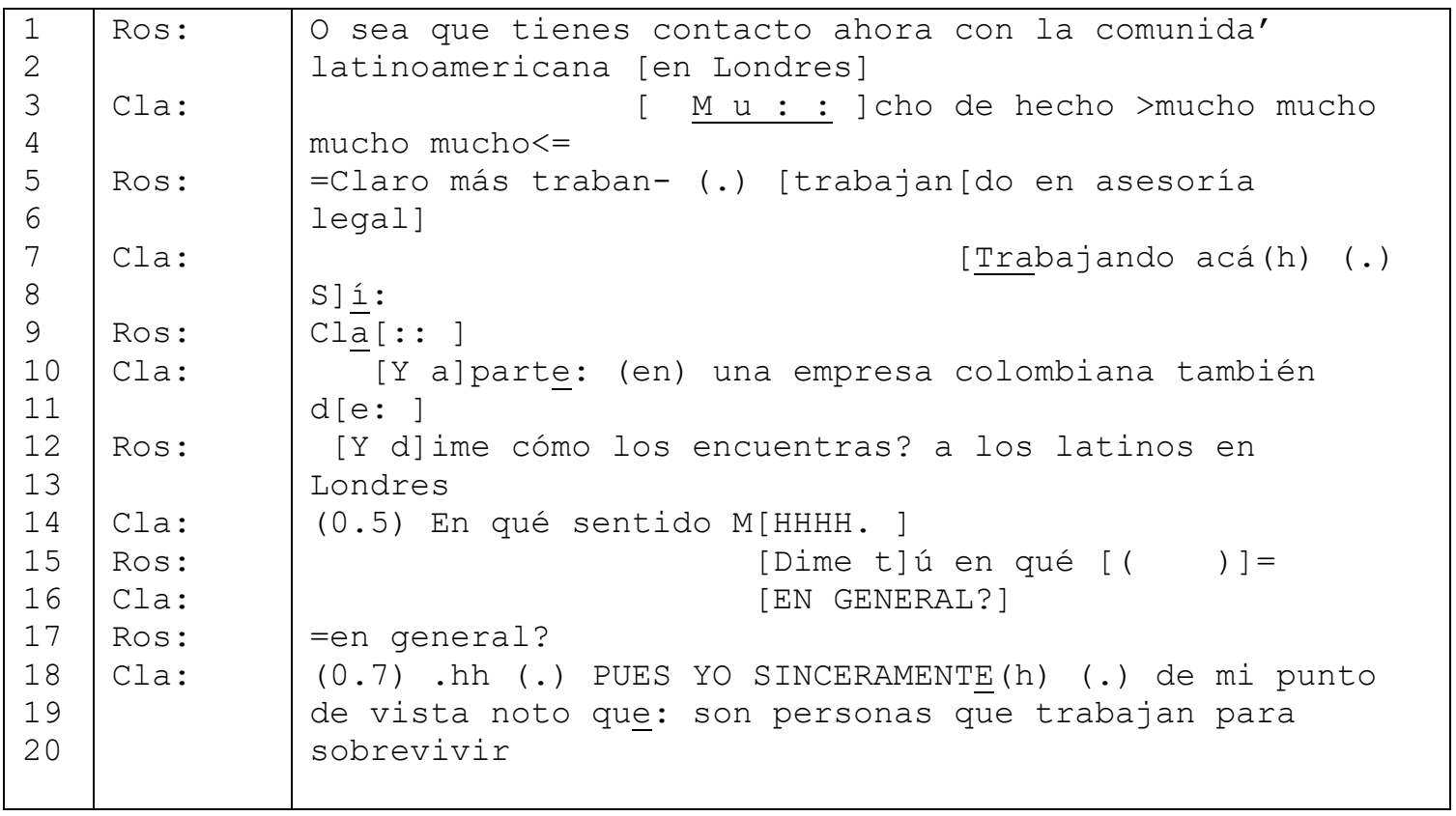

In this excerpt, Claudia co-constructs with the researcher her own position as a knowledgeable person based on her institutional ascription and her experience with other SsLAs. Thus, to Rosina's question in 1.1, Claudia confirms contact with the SsLAs and her experience. Then in 1.5, Rosina makes relevant Claudia's current work in legal advice, and 
Claudia specifies in 1.10 that it is in a Colombian company. We will observe how the fact that Claudia works in an office will frame the ways in which she constructs knowledge of her coethnics. In 1.12, the researcher Rosina reformulates 'Latin Americans' as 'Latinos in London' when asking Claudia a question. After asking for clarification in 1.14, Claudia aligns herself with the category 'Latino'. She answers the question with a critical attribution in 1.18, preceded by a hesitation which indicates her orientation to the potential interpersonal sensitivity of the topic at hand (indicated by the silence 0.7 ) and the stance she takes: de $m i$ punto de vista - 'from my point of view', which is nonetheless supported by her lived experience of dealing with Latin Americans in London (noto - 'I notice'). This stance allows Claudia to reinforce her discursive presentation as somebody who knows what she is talking about.

From now on during her interview, Claudia will continue co-constructing the category 'Latinos in London' by using 'erasure', that is, by assigning a reduced set of specific characteristics, taken to be 'natural' and universal among 'those' kinds of people (Irvine and Gal 2000).

Excerpt 5 - What Claudia knows

\begin{tabular}{|c|c|c|}
\hline $\begin{array}{l}48 \\
49 \\
50\end{array}$ & Cla: & $\begin{array}{l}\text { (...) Me gusta la gente latina me junto con la gente } \\
\text { latina PERO (.) hay cosas que no me cuadran }{ }^{\circ} \text { de la } \\
\text { gente latina }\end{array}$ \\
\hline 51 & Ros: & Como eso [por ejemplo( ) ] \\
\hline $\begin{array}{l}52 \\
53\end{array}$ & Cla: & $\begin{array}{l}\text { [Como E:so co]mo en cambio la gente inglesa } \\
\text { te muestra otras cosas. }\end{array}$ \\
\hline 54 & Ros: & $M:(h)$ \\
\hline 55 & Cla: & Sí a ver más allá pues de tus narices de: $(\mathrm{h})=$ \\
\hline 56 & Ros: & $=(($ carraspeo $))=$ \\
\hline 57 & Cla: & $=$ hay más mundo no?= \\
\hline 58 & Adr: & $=\mathrm{M}(\mathrm{h})$ \\
\hline $\begin{array}{l}59 \\
60\end{array}$ & Ros: & $\begin{array}{l}\text { Y lo latinoamericanos que conoces de aquí de dónde son } \\
\text { Colombianos? }\end{array}$ \\
\hline 61 & Cla: & . HH colombianos (.) la mayoría(h) s(h)í(h) \\
\hline 62 & Ros: & Sí: y conoces alguna otra nacionalida'?= \\
\hline 63 & Cla: &.$\overline{\mathrm{H}} \mathrm{H}$ \\
\hline 64 & Adr: & $=$ que [no sea colombiana?] \\
\hline 65 & Cla: & {$\left[\begin{array}{lllllllll}E & : & : & : & : & : & : & \end{array}\right]$} \\
\hline$(\ldots)$ & $(\ldots)$ & $(\ldots)$ \\
\hline 78 & Cla: & $=. \mathrm{HH}$ (.) Pero me gusta mucho la cultura de:(h) por \\
\hline 79 & & ejemplo >(la) comida (peruana)< riquísima \\
\hline 80 & Ros: & M: : : \\
\hline
\end{tabular}


Claudia continues to fill out the category 'Latinos in London' by distancing herself from them and, as we later learn. In 1. 48, she accepts that she hangs around with Latino people as a way to mitigate the set of attributions she will assign to them over the course of the interview. At the end of 1.50 she projects a set of negative attributions onto Latin Americans and carefully orients herself towards this, as observed by her use of softer speech to formulate the category of 'the Latino people'. Upon interpreting Rosina's question as giving her the goahead to create a truism in 1.52 , she responds by offering an implicit metacultural assessment, constructed by opposing the dominant supposedly homogeneous group la gente inglesa - 'the British people', represented as cosmopolitan $(1.53,1.57)$ to the equally homogeneous minority Latin American group as non-cosmopolitan. Despite the group's diversity, the implication that 'Latinos' in London' are a homogeneous, somewhat limited group, coupled with the observations made during our fieldwork (e.g. Colombian run restaurants have a primarily Colombian clientele, Peruvian restaurants with a principally Peruvian clientele, etc.), led the researcher to pose a question aimed at untangling what 'Latinos in London' means for Claudia. In 1.59, Rosina asks Claudia to state the precise origin of her friends. In 1.61, Claudia confirms that they are mostly Colombians. In 1.65, after a long hesitation and after being challenged by Rosina to identify the members of the Latin American community she knows, Claudia manages to include Ecuadorians. Importantly, in 11.78-81, she offers a definition of what she understands by 'culture'. Food is the basis of her intercultural knowledge pero me gusta mucho la cultura de:(h) por ejemplo >(la) comida (peruana)< riquísima - 'but I really like the culture:(h) for example >(the)(Peruvian)food $<$ delicious'. She reduces culture to a superficial example, something we characterise as banal interculturalism, which, ironically, 
displays her own lack of cosmopolitanism and her life in London as primarily led amongst a limited subset of Latin Americans.

Excerpt 6-Marking people: The exemplary migrant

\begin{tabular}{|c|c|c|}
\hline $\begin{array}{l}37 \\
38 \\
39\end{array}$ & Ros: & $\begin{array}{l}\text { Y ese tipo de clientela te llega aquí: (.) con r- con } \\
\text { problemas con los impuestos es reciente? gente } \\
\text { que hace poco que está en Londres? }\end{array}$ \\
\hline 40 & Cla: & M::: , (.) sí / la mayoría vienen de España \\
\hline 41 & Ros: & Exacto \\
\hline 42 & Cla: & La mayoría la mayoría ve- (.) vienen de España \\
\hline 43 & Ros: & ${ }^{\circ}$ Aha ${ }^{\circ}$ HHhhhhhh \\
\hline 44 & Cla: & No hablan el idioma \\
\hline 45 & Ros: & $E\left[\begin{array}{lllll}x & a & c & t & o\end{array}\right]$ \\
\hline 46 & Cla: & {$[($ eso es $)]($.$) en parte [s(\quad)]$} \\
\hline 47 & Ros: & y [tra]bajos de limpieza \\
\hline 48 & Cla: & Y trabajo- la mayoría trabajan en limpieza / sí \\
\hline 49 & Ros: & \\
\hline 50 & Cla: & .HH por ejemplo cuando mucha gente me preguntaba \\
\hline 51 & & (.) en qué trabajas y yo (.) nunca he trabaj''o en limpieza \\
\hline 52 & & (.) desde que llegué a aquí (.) y me dicen pero por qué: \\
\hline 53 & & ${ }^{\circ}$ pero ${ }^{\circ}$ porqu (h)e hay otr (h) as cosas \\
\hline 54 & & más uno tiene que ponerse las $\overline{\text { pilas }}$ en aprender el idioma y \\
\hline 55 & & 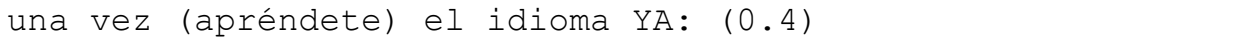 \\
\hline 56 & & .hh o sea trabaja un tiempo en limpieza pero no te tires \\
\hline 57 & & veinte años trabajando 'lo mismo y no hables inglés (.) o \\
\hline 58 & & sea es- \\
\hline 59 & Adr: & Porque la gente tiende a queda:rse \\
\hline 60 & Cla: & $\mathrm{E}(\mathrm{h})-($.$) se \mathrm{ACOMO}[\mathrm{D} A \mathrm{~N}]$ \\
\hline 61 & Adr: & {$\left[(\right.$ en) do $]$ nde llegan $\left.\left[()_{1}\right)\right]$} \\
\hline 62 & Cla: & {$[$ se- una vez $]$} \\
\hline 63 & & están cómodos se quedan ahí \\
\hline
\end{tabular}

This example, presents the ways in which Claudia marks people and how, one of the ways to construct banal interculturalism discursively is constructed in the rhetorical opposition between your own behaviour and that of 'others'. In this excerpt, she continues assigning attributes to the category Latinos en Londres by adding a new sub-classification in response to Rosina's question on recent changes in the SsLA landscape, in 1.40 - sí / la mayoría vienen de España - 'yes / most of them come from Spain'. Erasure continues to be the semiotic form of representing these people (1.44) No hablan el idioma - 'They don't speak the language', (1.48) la mayoría trabajan en limpieza / sí - 'most of them work in cleaning / yes', (L. 60) se ACOMO[ $D A N]$ - 'they GET COM[ F O RTABLE]'. In the small story (Georgakopoulou, 2007) initiated in 1.50, Claudia portrays herself as the cosmopolitan, visionary person that she 
typically associates with British people in opposition to the non-ambitious migrants. Thus, in an enacted conversation in the narrated world, when she is asked by other migrants about what she does for living, instead of replying with what she does, Claudia replies stating what she does not do: yo (.) nunca he trabaj'o en limpieza (.) desde que llegué a aquí - 'I’ve (.)

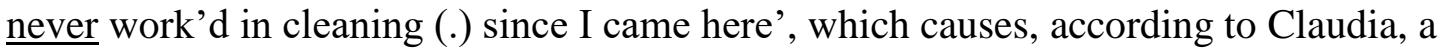
reaction of surprise from the her interlocutors (1.52). Such an opposition in this imagined conversation allows her to initiate a long evaluation, where the characteristics of the exemplary migrant are made explicit—hay otr(h)as cosas más. uno tiene que ponerse las

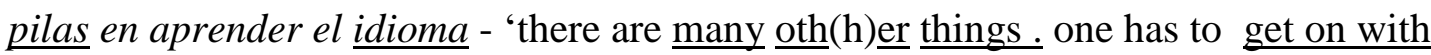
learning the language', trabaja un tiempo en limpieza pero no te tires veinte años trabajando lo mismo y no hables inglés - 'work in cleaning for a while but don't spend twenty years working at the same thing and not speaking English'. Claudia constructs implicitly the taboo of cleaning by creating a distance between what is 'normal' for other migrants and her own situation as an exemplary migrant who learns, is curious, and has ambition. (see also Block, 2007 and Morales, in press).

Claudia also offers a picture of a social group lacking mobility but comfortable in their current situation, distancing herself from the migrants engaged in menial work to whom she refers. Claudia, unlike Luci, makes migrants accountable for their own marginalisation.

\section{Discussion}

The discursive construction of banal interculturalism has been addressed in an interview situation with two economic migrants of Latin American background, employees in E\&C, London. Based on our observations during a year-long linguistic ethnography in the area, and our previous research with Latin Americans in, Barcelona, London and Madrid, we have defined banal interculturalism as a form of knowledge that emerges in the discourses that 
circulate among (SsLA) migrants about other (SsLA) migrants. By paying close attention to the discourses co-produced in the situated communicative arena of interviews between two female interviewees and two female researchers, all of Latin American background, we have identified the discursive resources and the discursive moves that allow migrants to talk and spread ideas, beliefs, definitions and impressions about co-ethnics. This form of knowledge, whose sources are hearsay or first hand contact, is the basis of the discourses that circulate among and about the members of this social group. It can be used for various, and sometimes contradictory, purposes such as seeking distance or closeness, as we observed by the presence of humour and its (non)affiliative reactions in our interaction with Luci. In our data, these discourses index symptoms of the complex intercultural relationships of the studied group, and allow us to understand, among other things, the lack of solidarity reported in previous research in the field (Block. 2007; McIlwaine, 2011; Cock, 2011; Márquez Reiter \& PatiñoSantos, 2017), but also forms of sociality. Thus, banal interculturalism in the E\&C area might entail negative consequences, mainly for SsLAs who do not speak English and rely on this space for employment and to establish social relations. If members of a particular group are portrayed negatively, it can prevent other Latin Americans from hiring them as employees, associating with them as business partners or including them in their circles of friends. On the other hand, if a particular group is portrayed in a positive way, it facilitates inclusion in various working and social activities and the establishment of mixed groups of SsLA friends and business partners, as we saw in the case of the hairdresser in $\mathrm{E} \& \mathrm{C}$, where a Uruguayan and a Spanish employee work for a Colombian boss. For that reason, we strongly believe that the contexts in which forms of banal interculturalism are produced need to be investigated and not taken for granted. It may also reveal the artificial nature of the category Latin American, as a political or commercially orientated construct bringing together a diverse collection of sub-groups in diaspora, with significant cultural differences. 
The interview situation turned out to be a suitable locus to position ourselves as subjects who wanted to discover, or wanted to exchange or confirm our knowledge with the participants. During the interview, we tried to position them as knowledgeable subjects whose opinions were important to us. As knowledgeable subjects, the two females interviewed constructed subjectively 'informed' portrayals of the 'others' - Luci about Colombians and Claudia about 'Latinos in general' - by adopting the categorisation 'Latino' that we offered her during the interview. Both 'knowledgeable subjects' presented evidence for their definitions and evaluations of the 'others" behaviour and moral values, based on various factors such as length of time resident in the receiving country, contact with co-ethnics, personal and experience and hearsay. These sources of evidence were central in stating "truths" gleaned about the 'others' that they presented and evaluated.

From our discursive perspective grounded in ethnographic fieldwork we systematised the most important forms of constructing banal interculturalism in the situated arena of the interview. Thus, the discursive semiotic resources used by the speakers in order to construct it are erasure, through generalisations, comparing "us" with "them" by assigning positive attributes (behaviour, moral conduct) to 'us', while the 'others' (in the case of Luci, Colombians) are presented through negative categorizations, and superficial examples of what characterizes a particular national group. As in any other identity construction, these two participants constructed and assessed both explicitly but also implicitly. Such forms of evaluation convey the way in which the participants construct themselves, in opposition to what is stated/evaluated regarding the 'others' by presenting exaggerated group attributes and distancing from 'them'. Thus, Luci contrasted Uruguayan moral values with Colombians' values (solidarity/exploitation) and Claudia constructed 'other' Latin Americans as passive and unambitious, portraying herself as a young person with higher aspirations. Her prejudices against cleaning jobs emerged on various occasions by presenting 'others' as focussed on the 
immediate rather than the long term concerns of life. Luci and Claudia construct hierarchies of people. Luci portrays Colombian migrants who arrived in the 1980s and 1990s as having the material resources necessary to succeed in diaspora, by among others, profiting from those co-ethnics who do not. Claudia also portrays hierarchies based on narratives of success and ambition. She contrasts those who are able to navigate the new social structures by learning English and widening their horizons beyond cleaning work with those who simply conform to a life of occupational and social immobility.

Finally, Luci and Claudia have a different approach to knowledge. While Luci evaluates based on what she has observed over ten years, and on her relationships with Colombians, Claudia expresses prejudices based on what she imagines the migratory experience to be, a world inviting curiosity that Latin Americans do not exercise. We believe that the notion of banal interculturalism, as it appears to emerge in mundane interactions, may allow us, as researchers working on intercultural communication and the sociolinguistics of globalisation, to look at how internal relations within a group are exercised and the consequences for migrants of the discourses they themselves spread within the wider group. Without organising themselves collectively, the SsLAs in London and the UK will find it difficult to construct themselves as a nationally recognised ethnic group, something that might give them access to social benefits, but also promote the visibility they need in order to participate as citizens (McIlwaine \& Bunge, 2016).

This said, the notion of banal interculturalism would benefit from future study and refinement. The extent to which it is a useful analytical tool can only be established through further empirical evidence, including other cultural groups.

\section{Acknowledgments}


We would like to thank David Block for his comments on an initial draft of this paper as well as the reviewers for their valuable comments.

\section{References}

Aranda, E. M., Hughes, S., \& Sabogal, E. (2014). Making a life in multiethnic Miami: Immigration and the rise of a global city. Boulder, CO: Lynne Rienner Publishers, Incorporated.

Atkinson, R. (1998). The life story interview. London: Sage.

Bailey, B. (2000). Communicative behavior and conflict between African-American customers and Korean immigrant retailers in Los Angeles. Discourse \& Society, 11(1), 86-108.

Billig, M. (1995). Banal Nationalism. London: Sage.

Block, D. (2007) Second Language Identities. London: Continuum.

Bolden, G. (2009). Beyond Answering. Repeat-Prefaced Responses in Conversation. Communication Monographs 76 (2), 121-143.

Casey Review (2016) A review into opportunity and integration. OGL. December 2016. https://www.gov.uk/government/uploads/system/uploads/attachment_data/file/575973 /The_Casey_Review_Report.pdf

Cook, J. C. (2011). Latin American commercial spaces and the formation of ethnic publics in London. In McIlwaine, C. (ed.), Cross-Border Migration Among Latin Americans. European Perspectives and Beyond. (pp. 175-196). New York:: Palgrave/Macmillan.

Drew, P. (2003). Precision and exaggeration in Interaction. American Sociological Review 68 (6), 917-938.

Garapich, M. (2007). Odyssean refugees, migrants and power-construction of 'other' and civic participation within the Polish community in the UK. In Reed-Danahay, D. and 
C. B. Brettell. Citizenship, Political Engagement, and Belonging: Immigrants in Europe and the United States (pp. 124-143). New Brunswick and New Jersey: Rutgers University Press.

Georgakopoulou, A. (2007). Small stories, interaction and identities. Amsterdam: John Benjamins Publishing.

Goffman, E. (1967). On face-work. In E. Goffman (Ed.), Interaction ritual: Essays on face to face behavior (pp. 5-45). New York: Anchor Books.

Gutiérrez Rodríguez, E. (2010). Migration, Domestic Work and Affect. A Decolonial Approach on Value and the Feminization of Labor. New York: Routledge.

Granada, L. (2013) Latin Americans in London: language, integration and ethnic identity. $\mathrm{PhD}$ thesis, Aston University.

Hansen, M. B. \& Márquez Reiter, R. (2016) (Co-)Constructing Interpersonally Sensitive Activities Across Institutional Settings. Special Issue Pragmatics and Society 7 (4), 507-692.

Harris, A. (2013). Young people and everyday multiculturalism . New York: Routledge.

Hill, J. H. (1998). Language, race, and white public space. American Anthropologist, 100(3), $680-689$.

Irvine, J. \& S. Gal (2000) Language ideology and linguistic differentiation in Kroskrity, P (ed.) Regimes of language: ideologies, polities, and identities (pp. 35-83). Santa Fe: School of American Research Press.

Kelsall, S. (2015). Language Ideologies and Latinidad at a Latin American School in London. In Márquez Reiter and Martín Rojo (eds) A Sociolinguistics of Diaspora: Latino Practices, Identities, and Ideologies (pp. 138-150). New York: Routledge. Martins Junior, A. (2014) Lives in Motion - notebooks of an immigrant London. Denmark: Whyte Tracks. 
Márquez- Reiter, R. \& Patiño-Santos, A. (2017) The discursive construction of moral agents among successful economic migrants in Elephant \& Castle, London. Tilburg Papers in Culture Studies Babylon, Paper 194.

Márquez- Reiter, R. (2018) Interviews as sites of ideological work. Spanish in Context 15 (1): 54-76.

Márquez Reiter, R. \& Martín Rojo, L. (2015) The Dynamics of (Im)Mobility. (In)Transient capitals and linguistic ideologies among Latin American migrants in London and Madrid. In Márquez Reiter, R. \& L. Martín Rojo. (eds), A Sociolinguistics of Diaspora: Latino Practices, Identities and Ideologies. (pp. 83-101). New York: Routledge.

McIlwaine, C. (ed.). 2011. Cross-Border Migration Among Latin Americans. European Perspectives and Beyond. New York: Palgrave/Macmillan.

McIlwaine, C., Cock, J. C., \& Linneker, B. (2011) No Longer Invisible: The Latin American Community in London, Trust for London: London.

Mcllwaine, C. \& Bunge, D. (2016) Towards Visibility: the Latin American Community in London, Trust for London, London.

Morales, D. (in press). "Si me quedo aquí seguiré hablando español”. Ideologías lingüísticas en inmigrantes latinoamericanos en Londres. Revista Internacional de Lingüística Iberoamericana. Número 31.

Negrón, R. (2011) Ethnic Identification among Urban Latinos._El Paso, US: LFB Scholarly Publishing.

Paffey, D. (in press) Spanish language visibility and the 'making of presence' in the linguistic landscape of London. In Lynch, A. (ed.) Handbook of Spanish in the Global City. New York: Routledge. 
Pavlenko, A. \& Blackledge, A. (2004) Negotiation of Identities in Multilingual Contexts. Clevedon: Multilingual Matters.

Piller, I. (2012) Intercultural Communication: An Overview. In C. B. Paulston, Kiesling, S.F. and Rangel, E.S. (eds.) The Handbook of Intercultural Discourse and Communication (pp. 3-18). Chichester, WS: Blackwell Publishing.

Pomerantz, A. (1986) Extreme case formulations: a way of legitimizing claims. Human Studies 9, 219-229.

Román-Velázquez, P. (1999) The Making of Latin London: Salsa Music, Place and Identity. London: Ashgate.

Roman-Velázquez, P. \& Hill, N. (2016). The case for London's Latin Quarter: retention, growth, sustainability. London: Latin Elephant. https://dspace.lboro.ac.uk/dspacejspui/handle/2134/21844 [Accessed 02/03/2017].

Roth, W. (2016) The multiple dimensions of race. Ethnic and Racial Studies, 39:8, 13101338.

Sandercock, L. (2003). Planning in the ethno-culturally diverse city: A comment. Planning theory \& practice, 4(3), 319-323.

Urciuoli, B. (1996). Exposing Prejudice: Puerto Rican experiences of race, class, and language in the US. Boulder, CO: Westview.

Urciuoli, B. (2011). Discussion essay: Semiotic properties of racializing discourses. Journal of Linguistic Anthropology, 21(1), E113-E122.

Yuval-Davis, N. (2012) The Politics of Belonging. Intersectional Contestations. London: Sage.

Zentella, A. C. (2003). José, can you see?: Latin@ responses to racist discourse. In D. Sommer (Ed.), Bilingual games. Some literary investigations (pp. 51-66). New York: Palgrave Macmillan US. 


\footnotetext{
${ }^{1}$ The struggle for recognition is still ongoing. Latin Americans have achieved ethnic recognition in some of boroughs in London where they are settled (Southwark, Lambeth, Islington and Hackney) but are still campaigning to make their presence visible in others such as Newham, Brent and Haringey (CLAUK, 7/11/2017) as well as in other cities in the UK (see, for example, Gutiérrez Rodríguez 2010). This coupled with the gentrification of deprived areas in London where they have mainly settled offers a grim picture of the future for them as well as for other groups. Their pan-identification as Latinos or Latin Americans partly responds to their struggle for ethnic recognition. Even though SsLAs come from different countries in Central and South America, we consider them as co-ethnics in the sense that they construct themselves discursively as members of the same community (Márquez-Reiter \& Patiño-Santos, 2017). Such a community is referred as Latino, South Americans and Latin Americans indistinctively in our ethnographic data, and it is based on historical links, and shared cultural traits from which Spanish language, in their own varieties, appears to be the most relevant. ${ }^{2}$ Although Brazilians are the largest group of Latin Americans in London, they do not tend to identify themselves as Latin Americans outside official domains (Martins Junior, 2014). They are also primarily concentrated in the borough of Brent, yet another area of London that will soon be gentrified thus potentially also displacing their many businesses.

${ }^{3}$ Similar situations have been reported for Polish migrants in the UK and indeed for other migrant groups, too. Despite their different migration trajectory, Poles are roughly the same size as Latin Americans and have also suffered downward mobility. There seems to be a social division between old groups of Poland exiles, associated to the values of the "Poles" who supported the UK during the WWII, and those who recently arrived as economic migrants after Poland's entry to the EU. The latter are seen as merely searching for economic opportunities (Garapich 2007).

${ }^{4}$ Most of the retailers and employers in the shopping centre were at the time of our ethnography of Colombian origin.
} 